\title{
Cien años de soledad: the Critique of Sophism and Pseudo-Science
}

\author{
William O. Deaver ${ }^{1}$
}

In brief, this study explores the philosophical underpinnings of García Márquez's 1967 novel and his ludic nature in dealing with critics who fail to perceive the comic nature of the novel. In addition, I explain the importance of toxic chemical and botanical substances used as curatives in the novel which critics have accepted at face value without considering that these remedies lead to sterility, birth defects, and death. The quest for knowledge within the novel parodies critical stances that unquestioningly accept what is read. [Article copies available for a fee from The Transformative Studies Institute. E-mail address:_journal@transformativestudies.org_Website: http://www.transformativestudies.org (C2013 by The Transformative Studies Institute. All rights reserved.]

KEYWORDS: García Márquez, Colombia, Medicine, Philosophy, Pharmakon, Solitude.

I first read One Hundred Years of Solitude in 1982 for an undergraduate seminar that explored the philosophical novel. Later, I would read Cien años de soledad many times in Spanish as well as scores of articles to understand its philosophy, which Kay García broadly defines as, “. . .el mensaje filosófico de la obra: que todo está escrito, no se puede escapar del destino. La vida es una serie de repeticiones de lo ya hecho, de lo ya escrito, con pequeñas diferencias significativas" (75). Few of the studies that I have read seem to incorporate Socrates's ideas into their analyses. Of course some of them mention bits and pieces of Socrates's dialogues that are detailed in Plato's works, but only as they are convenient to manipulating text. Some are utterly absurd and lack a critical perspective

\footnotetext{
${ }^{1}$ Dr. William O. Deaver, Jr. holds a BA in English and an MA in Spanish from the University of Virginia as well as a Ph.D. in Spanish from Florida State University. He is a professor of Spanish at Armstrong Atlantic State University, where he has taught for the last eighteen years. In addition to teaching, he directs the study abroad program in Mexico and the Latin American Studies Certificate. He has published on Gabriel García Márquez, Mario Vargas Llosa, Pío Baroja, Roberto Fernández, Tomás Gutiérrez Alea, Guillermo del Toro, Miguel Piñero, among others. Address correspondence to: Bill Deaver; e-mail: bill.deaver@armstrong.edu.
} 